\title{
Analisis Elastisitas Balok Baja Kantilever Akibat Beban Siklik
}

\author{
Hamsyah \\ Program Studi Teknik Sipil, Fakultas Teknik Universitas Muhammadiyah Parepare \\ Email aca.archa@yahoo.co.id
}

\begin{abstract}
ABSTRAK
Penelitian ini bertujuan untuk menganalisa regangan lentur dan regangan geser yang terjadi pada kantilever baja akibat beban berulang dan mengetahui besarnya beban yang bekerja pada baja kantilever. Pengujian beban berulang terhadap kantilever baja menggunakan referensi SNI dan ASCE 2005. Pengujian dilakukan dengan model fisik laboratorium dengan desain dibuat dengan metode pengujian balok kantilever berukuran $400.200 .13 .8 \mathrm{~cm}$ dengan panjang 1.060 meter untuk sambungan balok kantilever digunakan sistem end plate connetion, baut yang digunakan adalah baut mutu tinggi A325 diameter $\varnothing 19 \mathrm{~mm}$, jumlah baut 12 penempatan baut dapat dilihat pada gambar 3.2, dan tebal plat $10 \mathrm{~mm}$ dilas keliling 70 Ksi dengan tebal las $8 \mathrm{~mm}$ pada ujung balok kantilever. Sementara pola pembeban dilakukan secara berulang dan kemudian dibandingkan dengan perhitungan analisis dengan aplikasi numerik program komputer. Hasil pengujian yang dilakukan, kapasitas beban lateral naik seiring dengan pertambahan displacement. Pengujian terhadap load contolled dan displacement controlled pada benda uji menunjukkan perilaku yang hampir sama pada zona elastik. dimana kekakuan pada benda uji yang relatif sama terlihat dari garis lurus yang berimpit pada kurva benda uji dan regangan yang terjadi pada flens dan web dari balok kantilever masih pada tahap elastisitas.
\end{abstract}

Kata kunci : Beban berulang, balok kantilever, baja.

\section{ABSTRACT}

This study aims is to analyze the bending strain and shear strain that occur in steel cantilever due to cyclic loading and to find out the size of the load acting on the steel cantilever. The testing of cyclic load on steel cantilever was conducted by using SNI and ASCE 2005 references. The tests were conducted by using the laboratory physical model with desaign made by measuring the cantilever beam of 400.200 .13 .8 and a length of 1.060 meters. The end plate connection system was used for the connection of the cantilever beam. The were 12 bolts of high quality (A325) with a diameter of $\varnothing 19 \mathrm{~mm}$. The plate was $10 \mathrm{~mm}$ thick, and it had circumferential weld (70 Ksi and $8 \mathrm{~mm}$ thick) at the tip of the cantilever beam. The loading pattern was done repeatedly, and was compared with analytical calculation by using computer program numerical application. The test shows that lateral load capacity increased along with the increase of displacement. The test of load and displacement controlled on the specimen shows behavior almost similar to elastic zone. The stiffness of the test specimen is relatively equal as the straight line coincides with the curve of the test specimen, and the strain occurring in the flange and web of the cantilever beam is still at the stage of elasticity.

Keywords : Cyclic Load, cantilever beams, steel.

\section{PENDAHULUAN}

Suatu balok baja kantilever yang diberikan beban vertikal terpusat di ujung akan mengalami deformasi vertical. Pada hakekatnya benda yang mengalami tegangan akan menimbulkan deformasi. Deformasi ini sangat berhubungan erat dengan besarnya gaya yang menyebabkannya.

Regangan merupakan bagian dari deformasi, ada hubungan umum antara tegangan dan regangan untuk material elastis yang pertama kali dinyatakan oleh Robert Hooke (1635-1703) dan dikenal sebagai hukum Hooke. Dalam hukum Hooke dijelaskan hubungan antara tegangan dan regangan, dimana hubungan ini menggambarkan keadaan yang terjadi pada batang baja lunak yang ditarik gaya aksial tertentu pada kondisi temperatur ruang. Dari hubungan ini diperoleh bahwa nilai regangan yang terjadi berbanding lurus dengan tegangan atau beban aksial yang diberikan pada batang tersebut. Kondisi ini yang kemudian disebut sebagai kondisi elastis [1] [2] [3].

Pembebanan yang lebih cepat seperti akibat pukulan palu, gempa bumi atau ledakan nuklir dapat merubah sifat tegangan regangan. Umumnya kenaikan laju regangan akibat beban dinamis menaikan titik leleh, kekuatan tarik dan daktilitas. Pada suhu tertentu terjadi penurunan kekuatan yang cukup berarti. Ketegasan juga akan meningkat dengan laju regangan yang tinggi, tetapi kelihatan berkaitan dengan factor lain seperti tekik tempat konsentrasi tegangan dan pengaruh suhu. 
Factor yang lebih penting dari pembebanan dinamis bukanlah laju pertambahan regangan yang cepat, tetapi gabungan dengan laju penurunan regangan yang cepat [4] [5].

Dilihat ketika sebuah balok lurus yang menerima beban-beban lateral mengalami momen lentur dan gaya geser pada setiap penampangnya

Pada kasus yang umum terjadi Suatu balok baja kantilever yang diberikan beban berulang di ujung akan mengalami regangan lentur dan regangan geser pada setiap penampangnya. maka pada penelitian ini akan diteliti mengenai pengaruh beban berulang terhadap kantilever baja [6] [7].

\section{BAHAN DAN METODE}

\section{Lokasi dan Rancangan Penelitian}

Untuk memperoleh data dalam penelitian ini dilakukan di laboratorium Bahan Dan Struktur Jurusan Teknik Sipil, Fakultas Teknik, Universitas Hasanuddin Makassar. Benda uji yang digunakan adalah baja WF 400x200x13x8 yang dimodelkan berupa balok kantilever dengan perletakan jepit pada salah satu ujung balok.Penelitian dilakukan dengan memberi gaya horisontal berulang pada benda uji balok kantilever tersebut sedemikian sehingga diperoleh keadaan defleksi murni. Setting pengujian dan setting pembebanan balok kantilever di laboratorium [8] [9].

\section{Pembuatan Benda Uji}

Pada pembuatan benda uji ini digunakan skala geometri $1: 1$. Benda uji balok kantilever pada penelitian ini menggunakan profil WF 400x200x13x8.yang dirakit dengan panjang balok

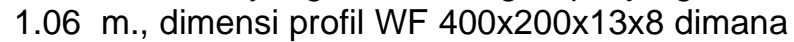
$\mathrm{d}=400 \mathrm{~mm}$, bf $=200 \mathrm{~mm}$, tw $=13$ dan $\mathrm{tf}=8 \mathrm{~mm}$. Untuk sambungan balok kantilever digunakan sistem end plate connetion, baut yang digunakan adalah baut mutu tinggi A325 diameter baut $\varnothing 19$ $\mathrm{mm}$, jumlah baut 12 penempatan baut dapat dilihat pada gambar 3.2 , dan tebal plat $10 \mathrm{~mm}$ dilas keliling $70 \mathrm{Ksi}$ dengan tebal las $8 \mathrm{~mm}$ pada ujung balok kantilever.

\section{Pemodelan Benda Uji}

Pengujian Pengaruh beban berlulang terhadap balok Kantilever, dilakukan terhadap benda uji berupa Balok kantilever yang salah satu ujungnya dijepit sedangkan ujung lainnya dapat berpindah mengikuti arah gaya terpusat yang bekerja bolakbalik pada arah tegak lurus sumbu balok. Perpindahan ini akan menimbulkan defleksi pada ujung kabtilever yang searah gaya geser. Pada Ujung jepit disambung dengan baut dan direncanakan berperilaku seperti yang dimodelkan. Set up pengujian benda uji di laboratorium dilakukan sesuai dengan pemodelan Balok Kantilever dengan menghubungkan salah satu ujung benda uji dengan Balok Baja WF sebagai Perletakan Kantilever, dan ujung lainnya dengan Hydraulic Jack yang bekerja dengan gerakan tarik-tekan dalam arah tegak lurus sumbu baja

\section{Pemasangan Benda Uji}

Perakitan benda uji dimana kedudukan kolom diletakan pada lantai yang diperkuat dengan angkur, kemudian balok kantilever diletakan tegak lurus terhadap kolom dan disambung mengggunakan sambungan type end plate connection seperti pada gambar 1 .

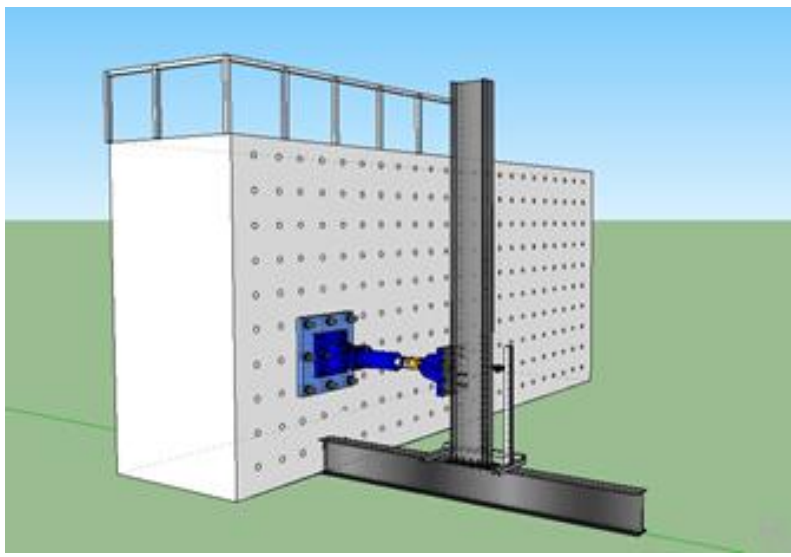

Gambar 1. Set up benda Uji

\section{Test Setup dan Instrumentasi}

Pembebanan diberikan melalui Hidraulik Jack pada ujung atas Balok berupa perpindahan siklik quasi statik yang diatur mengikuti pola pembebanan yang ditunjukkan dalam Pencatatan dilakukan selama pembebanan terhadap besarnya beban yang bekerja, pembacaan perpindahan ujung Baja kantilever menggunakan LVDT (Linier Variabel Differential Transformer) yang terhubung melalui kabel ke data logger. , dan Pembacaan regangan pada baja, yaitu regangan Lentur pada pelat sayap dan regangan geser pada pelat badan baja IWF menggunakan strain gauge yang terhubung melalui kabel ke data logger

Salah satu tujuan percobaan ini adalah mempelajari regangan lentur dan regangan geser pada Kantilever baja, maka pemasangan instrumentasi strain gauge dilakukan untuk mengamati perilaku lentur, sebanyak 2 buah strain gauge dipasang memanjang pada flange kiri (diberi kode G1 dan G2), dan sebanyak 2 buah strain gauge dipasang memanjang pada flange Kanan (diberi kode G9 dan G10). Sedangkan untuk mengamati perilaku geser, 5 buah strain gauge yang dipasang dengan $1 \mathrm{D}$ dari profil (diberi kode G3,G4,G5,G6 dan G7) 


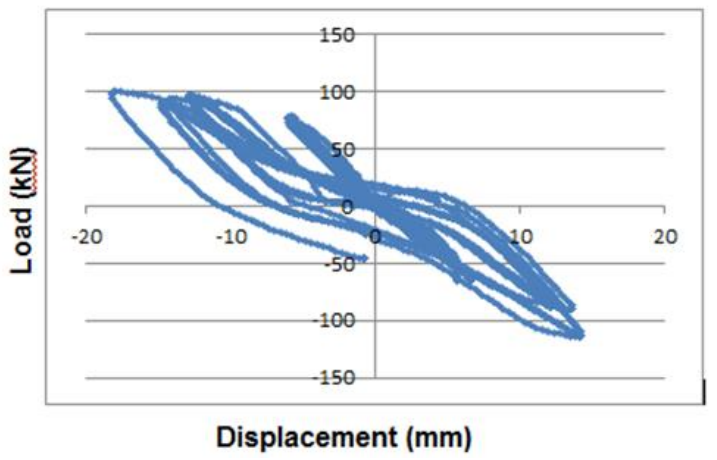

(a)

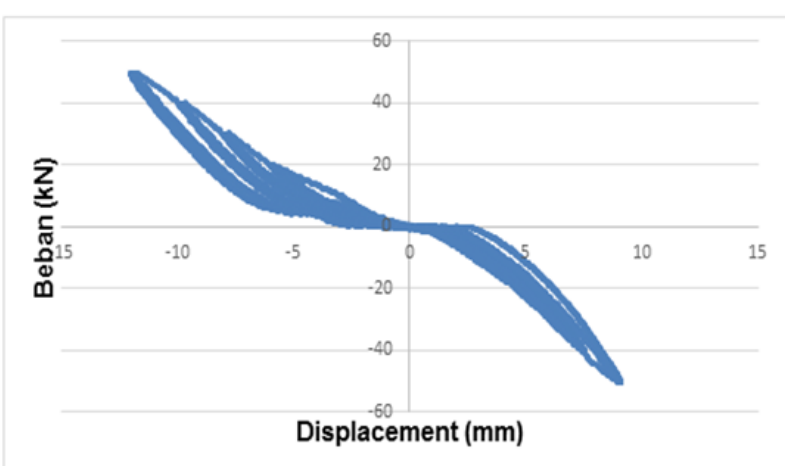

(b)

Gambar 2. Grafik hysteteric loops, (a). load controlled dan (b). Diplacement controlled

Tabel 1. Rekapitulasi perbandingan antara beban dan dispesmen

\begin{tabular}{cccc}
\hline $\begin{array}{c}\text { Beban }(\mathrm{P}) \\
(\mathrm{KN})\end{array}$ & $\begin{array}{c}\text { Displesmen }(\Delta) \\
\text { Analisis } \\
(\mathrm{mm})\end{array}$ & $\begin{array}{c}\text { Displesmen }(\Delta) \\
\text { SAP 2000 } \\
(\mathrm{mm})\end{array}$ & $\begin{array}{c}\text { Displesmen }(\Delta) \\
\text { Penelitian } \\
(\mathrm{mm})\end{array}$ \\
\hline 2 & 0.1675 & 0.1677 & 0.1010 \\
4 & 0.3350 & 0.3401 & 0.2745 \\
6 & 0.5025 & 0.5065 & 0.4280 \\
8 & 0.6701 & 0.6700 & 0.6550 \\
10 & 0.8376 & 0.8290 & 0.8304 \\
12 & 1.1554 & 1.1555 & 1.0312 \\
14 & 1.3780 & 1.3779 & 1.3550 \\
16 & 1.5331 & 1.5422 & 1.4985 \\
18 & 1.6557 & 1.6554 & 1.5250 \\
20 & 1.9887 & 1.9890 & 1.8466 \\
\hline
\end{tabular}

Pengujian dilakukan dengan memberikan beban siklik pada ujung balok yang disimulasikan dengan alat yang terdiri dari hydraulic Jack dengan kapasitas $1500 \mathrm{KN}$ yang dilengkapi oleh load cell, 2 (dua) buah LVDT untuk mengukur lendutan dan strain gauge yang dipasang pada Badan dan sayap untuk mengetahui regangan yang terjadi. Sistem

pembebanan yang dilakukan pada struktur balok kantilever mengacu pada pola pembebanan yang dilakukan dalam 2 (dua) tahap, yaitu tahap load controlled dan tahap displacement controlled.

Tahap load controlled adalah tahap dimana beban positif maupun beban negative ditentukan besarnya, kemudian dilakukan pengamatan terhadap defleksi yang terjadi, serta pembacaan regangan yang terjadi dari strain gauge yang dipasang pada sisi sayap dan badan balok kantilever.

Tiap siklus terdiri dari tiga putaran pembebanan, positif dan negatif. untuk pembebanan tahap kedua yakni tahap displacement controlled.
Tahap displacement controlled adalah tahap dimana defleksi lateral pada masing-masing siklus, dalam pengujian dengan kenaikan displesmen $4 \mathrm{~mm}, 8 \mathrm{~mm}, 12 \mathrm{~mm}, 16 \mathrm{~mm}$ dan seterusnya sampai retak tercapai. Tiap siklus pada tahap displacement controlled ini dilakukan sebanyak tiga kali putaran pembebanan.

Benda uji ditempatkan pada Strong Wall, dengan kolom dalam posisi mendatar di atas perletakan. Setting up benda uji dapat dilihat pada Gambar 1. Pembebanan siklik disimulasikan dengan alat hydraulic actuator yang mempunyai kapasitas 1500 KN. Hydraulic actuator diletakkan pada balok dengan jarak $100 \mathrm{~cm}$ dari muka kolom.

\section{HASIL DAN PEMBAHASAN}

1. Hubungan Beban dan Displesmen

Sistem pembebanan yang dilakukan pada struktur balok kantilever mengacu pada pola pembebanan dilakukan dalam 2 (dua) tahap, yaitu tahap load controlled dan tahap displacement controlled.Dari hasil pengujian Displacement controlled diperoleh 
hubungan beban dan defleksi yang dibuat dalam bentuk kurva hysteresis loop.

Dari gambar di atas dapat dilihat bahwa kapasitas beban lateral naik seiring dengan pertambahan displacement. Perbedaan beban lateral arah positif dan negative dimungkinkan karena perbedaan gerakan load cell untuk masing-masing arah, sehingga mempengaruhi defleksi lateral balok. Dan pada saat pengujian baut mengalami kendur dikarenakan pada saat pengancingan baut tidak menggunakan peralatan yang tepat menyebabkan kurva histerisis yang dialami oleh Balok Kantilever menghasilkan disipasi energi yang terbatas. Hal ini dapat terlihat dari bentuk kurva histersis yang langsing menunjukkan kinerja pelat sambung dan baut yang tidak cukup baik terhadap beban siklik..

Hasil pengujian terhadap load contolled dan displacement controlled pada benda uji menunjukkan perilaku yang hampir sama pada zona elastik. dimana kekakuan pada benda uji yang relatif sama terlihat dari garis lurus yang berimpit pada kurva benda uji. perbandingan antara load dan displacement yang dihasilkan oleh benda uji akibat pola pembebanan siklik, dengan beban puncak masing-masing pada load controlled adalah $49,2 \mathrm{kN}$ dan pada tahap displacement controlled adalah $11.105 \mathrm{kN}$, dan perpindahan maksimum masing-masing sebesar 11,895 mm dan $20 \mathrm{~mm}$

\section{Energi disipasi (Hystetericic Energy)}

Energi disipasi (Hystetericic Energy) merupakan luasan pada setiap siklus. Luasan loop di hitung dengan pendekatan numeric, dengan menganggap setiap luasan pias pada loop merupakan luasan persegi

\section{Hubungan Beban dan Regangan}

Kurva beban dan Regangan dari hasil pengujian balok kantilever dengan nilai pembebanan lateral balok kantilever loadcontrolled tekan dan loadcontrolled tarik serta balok kantilever diperoleh dari hasil pembeban bolak-balik setiap siklusnya. regangan yang terjadi pada flens dan web dari balok kantilever masih pada tahap elastisitas, dapat dilihat dimana garis pada grafik berbentuk linier, Bertambannya tegangan yang terjadi seiring dengan bertambahnya regangan, hal ini dapat dilihat dengan bentuk kurva yang linier.

\section{Kondisi kegagalan}

Akibat pembebaban siklik yang dilakukan, dapat diamati terjadinya mekanisme kerusakan dan kegagalan yang Terjadi pada benda uji. Pada Pengamatan menunjukkan besaran yang tercatat Pada displacement controlled $20 \mathrm{~mm}$ sambungan las pada benda uji sudah memasuki fase kerusakan yaitu mengalami retak pada hal balok kantilever masih berada pada fase inelastic. Hal ini terjadi karena sambungan las pada balok kantilever tidak mampu menyerapkan energy dengan baik pada sendi plastis sesuai dengan kinerja struktur balok kantilever.

\section{KESIMPULAN}

Dari hasil pengujian yang menunjukkan bahwa kinerja balok kantilever pada tahap displacement controlled memiliki hysteteric energy yang lebih besar dibandingkan dengan tahap load. Regangan yang terjadi pada flens dan web dari balok kantilever masih pada tahap elastisitas. Hasil pengujian terhadap load contolled dan displacement controlled pada benda uji menunjukkan perilaku yang hampir sama pada zona elastik. dimana kekakuan pada benda uji yang relatif sama terlihat dari garis lurus yang berimpit pada kurva benda uji. perbedaan tidak terlalu signifikan. Dimana pada saat beban mencapai $20 \mathrm{KN}$ displesmen pada analisi sebesar $1.988 \mathrm{~mm}$, Pada Pengamatan menunjukkan besaran yang tercatat Pada displacement controlled $20 \mathrm{~mm}$ sambungan las pada benda uji sudah memasuki fase kerusakan yaitu mengalami retak

Dalam pengujian dan analisa pada penelitian ini ada terdapat beberapa saran untuk melengkapi kekurangan-kekurangan yang dialami antara lain, Perlu diadakan penelitian lebih lanjut lanjut sampai batas. Plastis pada sambungan baut diperlukan alat yang memadai untuk proses pengkancingan. Perlu diperhatikan sambungan dalam pengertian sambungan harus diperkuat sehingga tidak terjadi kegagalan pada sambungan.

\section{DAFTAR PUSTAKA}

[1] American Institute of Steel Construction (AISC). (2005a), Prequalified Connections for Special and Intermediate Steel Moment Frames for Seismic Applications, ANSI/AISC 358-05, Chicago, IL.

[2] American Institute of Steel Construction (AISC). (2005c), Specification for Structural Steel Buildings, ANSI/AISC 360-05, Chicago, IL. Bowles, J.E. (1993

[3] James Newel, Uang, C.M yu , Cyclic Testing Of Bolted Flang Plate Steel Moment Connection For Special Moment Frames, Journal of Structural Engineering, ASCE

[4] Moestopo, M., Kusumastuti, D., Novan, A., 2008, Improved Performance of BoltConnected Link Due to Cyclic Load, Jakarta: 
International Conference on Earthquake Engineering and Disaster Mitigation.

[5] Moestopo, M., Mirza, A., 2006, Kinerja Sambungan Baut pada Link Struktur Rangka Baja Eksentrik, Seminar \& Pameran HAKI.

[6] Uang, C.M., Yu, Q.S., Noel, S., and Gross, J. (2000), "Cyclic Testing of Steel Moment Connection Rehabilitated with RBS or Welded Haunch," Journal of Structural Engineering, ASCE, Vol. 126, No. 1, pp. 57-68.
[7] Ramadan, T., Ghobarah, A., 1994, Behaviour of Bolted Link-Column Joints in Eccentrically Braced Frame, Canadian Journal of Civil Engineering, pp.745-754.

[8] SNI-03-1726-2002,Tata Cara Perencanaan Bangunan Tahan Gempa, Badan Standar Nasional

[9] SNI 03-1729-2002,Tata Cara Perencanaan Struktur Baja Untuk Bangunan Gedung, Badan Standar Nasional. 